\title{
Directions of Indonesian Islamic Law in the New Normal Era
}

\author{
Abidin $^{1}$ \\ \{ abidin@iainpalu.ac.id $\left.{ }^{1}\right\}$ \\ Institut Agama Islam Negeri Palu, Palu, Indonesia ${ }^{1}$
}

\begin{abstract}
There is a kind of anxiety in society after the government announced a pandemic Covid-19 in the era of new normal (al ta'ayusy) that the era of living side by side (not at peace) with pandemic Covid-19. While activities must return to normal. This fact requires a new Islamic law based on the integration of science, religion and culture using a multidimensional methodology through finding common ground. The research objective is to determine the content and methodology of the direction of Indonesian Islamic law in the new normal era. The results showed that it turns out that it is necessary to change Islamic law in Indonesia from the normal period to the new normal period in activities. In normal times: without masks, hand sanitizer and physical distancing consider to be halal while in the era of new normal it turns to be haram. The consideration of its haram without masks, hand sanitizer and physical distancing is understanding of the integration of science, religion and culture towards the pandemic in the new normal era which is rational. Methodological approaches used in the is multidimensional form of theology, figh, epidemiology, health, environment, economics, and sociology.
\end{abstract}

Keywords: Direction, Islamic Law, Indonesia, Multidimensional, New Normal

\section{Introduction}

This research is carried out to urge an immediate policy on the direction of Islamic law in the new normal era towards the activities of Indonesian society. This research's trend is due to the anxiety of many people after the Indonesian government announced the Covid-19 pandemic in the new normal.[1] (al-ta'ayusy) era, namely the era of coexistence (not peace) with Covid-19. Meanwhile, the economy, religious, and other social activities must continue to go on. Religious people must be able to perform worship again at their place of worship. The employees must immediately enter the office again. Students must immediately return to their learning environment. Anyway, everyone should get back to their routine. Therefore, there is no other way, all of us must live side by side with Covid-19 even if it remains hostile. We must commit to having a precautionary attitude in all sectors of life by putting health protocols above all to prevent the transmission of Covid-19 which can lead to death. [2]. The author assumes that the Indonesian people are unable to consistently maintain the Covid-19 protocol in the new normal era, especially in the fact that in society there are types of thinking based on religious postulates and explaining everything from a theological or figh perspective. This type of thinking is called al-bayan which gave birth to a religious tradition that only believes in religious' view in viewing the Covid-19 pandemic as something that you need not be afraid of. So that people like this tend not to wear masks, not doing physical distancing, and don't use hand sanitizers. Understanding like this during the Covid-19 pandemic, many were indicated by Covid and died. [3]The inconsistent attitude of 
the community in enforcing the Covid-19 protocol is due to the absence of a formal new Islamic law that uses considerations of integration of science, religion, and culture through a multidimensional approach by finding common points. Also, there is a lack of government (institutional) commitment to enforcing the COVID-19 pandemic health protocol. President Jokowi said that "there are not fewer people who do not adhere to health protocols but more because people are not disciplined in wearing masks, hand sanitizers and physical distancing on various fronts.[4]

From the description above, the main focus of this research is what is the direction of Indonesian Islamic law in the new normal era and how the new Islamic law methodology in determining the direction of Indonesian Islamic law in the new normal era.

\section{Literature Review}

This topic is interesting because no one has written scientifically about the direction of Indonesian Islamic law in the new normal era. The writer's wish in this topic is the change in the status of the old Islamic law to the status of the new Islamic law regarding the use of masks, hand sanitizers, and physical distancing. Activities without masks, without hand sanitizers, and physical distancing in the new normal era are halal according to old Islamic law because that era was normal (the Covid-19 pandemic had not yet occurred), but after the Covid-19 pandemic occurred, activities without masks, without hand sanitizer, and physical distancing are haram according to the new Islamic law.

Several literary explanations about the justification for changing Islamic law, include:

1. لا ينكرتغير الا حكام بتغير الزمان الزمان (the law inevitably changes due to changing times). [5]

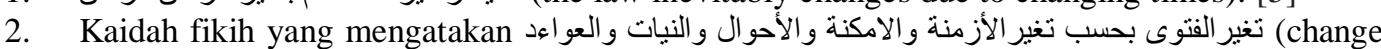
of fatwas due to changing times, places, circumstances, intentions, and habits). [6]

Ibn Qayyim argued that the principles and basis of Islamic law are wisdom and benefit for mankind, both in the life of the world and the hereafter.

3. Islamic law in the sense of fiqh (understanding) is dialectical, meaning that Islamic law is always ready to undergo reconstruction and deconstruction. [7]

What has been known from the changes in Islamic law in responding to the Covid-19 pandemic in the new normal era is that there are only four central MUI fatwas regarding the Covid-19 pandemic. MUI Fatwa No. 14 of 2020 concerning the implementation of worship which confirms that Friday prayers are allowed at home. Fatwa No.17 of 2020 concerning prayer guidelines for health workers who. treat Covid-19 patients. The fatwa confirms that Muslim health workers who are tasked with caring for Covid-19 patients wearing PPE are still obliged to perform fardhu prayers in various conditions and according to their abilities. Fatwa No. 23 of 2020 concerning the use of zakat, infaq, and alms assets to tackle covid-19, including overcoming the covid-19 outbreak and its effects are all efforts aimed at preventing the spread of covid-19. Fatwa No. 28 of 2020 concerning the guidance for takbir, kaifiat and Eid prayers in the congregation can be carried out at home. Likewise, the fatwas and views of the two major Islamic organizations, namely Nahdlatul Ulama and Muhammadiyah, issued fatwas and guidelines that strengthen MUI's fatwas. [8] 
From the explanation of the MUI fatwa, Islamic organizations, and several other views above, it is clear that there has been a direction of Indonesian Islamic law in the new normal era due to the reason for the Covid-19 pandemic, but in terms of changing Islamic law from Islamic law on the grounds of integration of science, religion and culture has not become the main discussion of previous writings. This paper focuses on the direction of Indonesian Islamic law in the new normal era based on the integration of science, religion, and culture using a multidimensional methodology through the search for common points. Techniques like this can produce new changes in Islamic law that are more beneficial and harmonious.

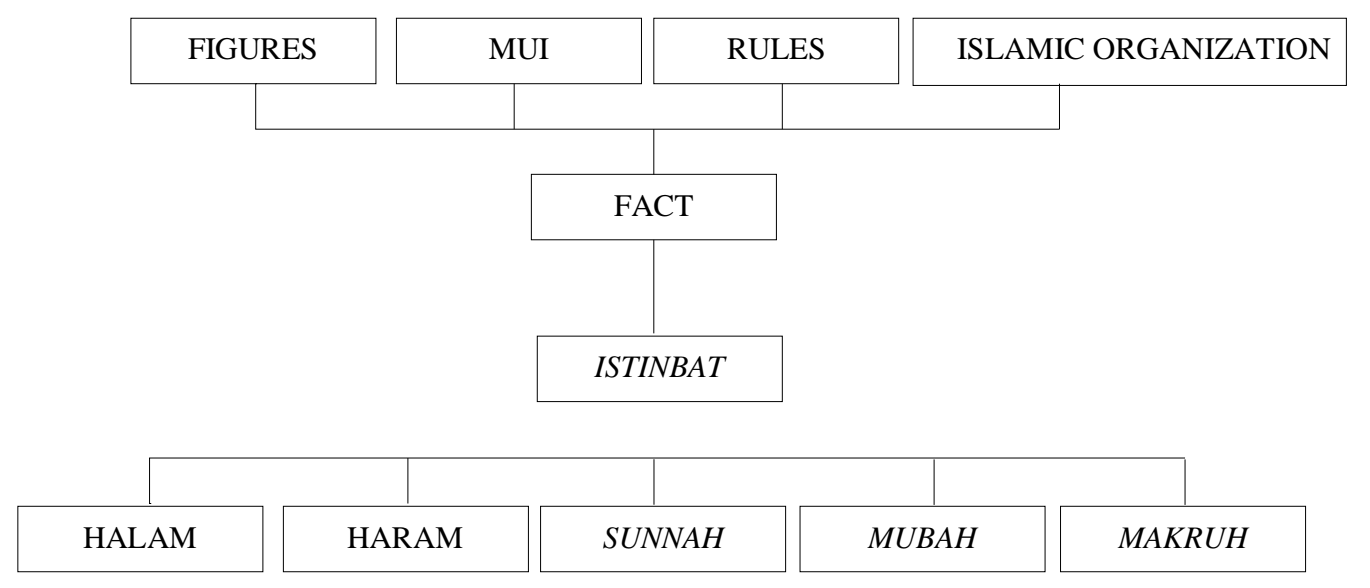

Figure 1 Changes of Islamic Law Scheme

\section{Methods}

This type of research is descriptive, which displays not only the questions that exist in the object of research but also on other variables related to the problem. The participants of this study were more directed to the analysis of observations, interviews, mapping, and analysis of literary texts, secondary.

Data analysis, online FGD. The unit of research analysis is text material relating to the direction of Indonesian Islamic law in the new normal era. The type of data needed is qualitative data. The ways to do this research are 1 . Observations to the general public, the government, the Indonesian Ulema Council, an Islamic community organization. Observations on the general public took a sample of Jakarta as the center of the capital city of Indonesia, a multi-ethnic center, education center, business center, and a religious center. The purpose of observing the general public is to get information on people's behavior about whether or not they obey the Covid-19 protocol. Observations on the government by taking samples from several Ministry offices in Jakarta to obtain information about government policies in enforcing the Covid-19 protocol in the new normal era. Observations to the central Indonesian Ulama Council in Jakarta to obtain information about the Covid-19 protocol fatwa in the normal New era. Observations to Islamic organizations by taking samples of central NU and Muhammadiyah to obtain information about Islamic mass organization policies in enforcing the Covid-19 protocol in a new normal era. 2. Interview with the figures by taking a sample of three people whom the author deems competent in explaining the direction of Indonesian Islamic law in the new normal era. 3. The mapping of literary texts is carried out from various readings related to the direction of Indonesian Islamic law in the new normal era. 4. FGD is conducted by inviting participants who can contribute to the content of the research object. 
The instruments used in observations, interviews, and FGDs were online via google forms, WhatsApp, zoom meeting, and video calls because coordination was easy during the covid-19 period. The function of this instrument is to provide input about the object of research. The added value of the instrument is to strengthen the argument besides literature.

The research was carried out starting from determining the title, determining the framework, determining the google form content, determining the literature, determining individuals and groups (organizations) that are eligible to be given Google Form filling, to collecting the results of Google Form filling. The length of this study was 1 month. The data collection situation was during the Covid-19 epidemic in the new normal era. Questions are asked to individuals and groups via WA and answered by filling in the google form then the answers are sent to the author via WA as well.

The data collection technique is done qualitatively by using observation, participant observation, in-depth interviews, FGD, and existing data (manuscripts, textbooks, memes, online news). Data analysis through data management processes (transcription, reduction through thematic classification, trends, frequency, and research objectives). Data presentation with tables, interview excerpts, summary. The level of analysis used is through restatement, description, interpretation. The analysis technique uses content analysis, critical discourse analysis, semantic analysis, and symbolic analysis.

\section{Results and Discussion}

\subsection{The main question $I$ is about the direction of Indonesian Islamic law in the new normal era}

Islamic law requires science, religion, and culture. Maslahat Islamic law can be achieved in the implementation of the integration of science, religion, and culture. Between science, religion, and culture, they should go hand in hand (harmoniously), not contradictory. So, it is hoped that the three of them will no longer appear friction or feud, but remain within their respective territories. This integration relationship will be the way to form the civilization that all parties dream of. So, for that, the real struggle of Islamic law is to build the integration of science, religion, and culture.

The word science (science) itself comes from the word science, scientia, scine which means knowledge. The word is synonymous with the word logos which means knowledge. According to Sudjana, science can be interpreted as knowledge that aims to find truth based on facts or natural phenomenans [9]. The word religion (religious) can be viewed in three meanings at once, 1) religious is a belief in the unseen which is the way of life for humans, 2) in religious there are rules, norms, and values, including worship that must be carried out solemnly and with care, 3) that the rules, norms, and values in religion grow and develop in human life, society, and culture [10].

While culture (culture) is the work, taste, and creation of humans/society. The work produces technology and material (material culture) that humans need. The sense which includes the expression of the human soul, including religion, ideology, spirituality, and art. Meanwhile, creativity is a mental ability, the ability to think of people, resulting in philosophy and science. All works, tastes, and copyrights are controlled by the initiative that determines its use to suit the interests of most of the whole of society [11]. Thus, understanding the definition between science, religion, and culture, where the three are entities integrated within the individual/society. Science is a theory or concept or idea of how we make something, while culture is a step, tool, and identity in creating something, while religion is a soul/spirit / moral / intuition in providing a definite direction. So that the three of them complement each other in forming a civilization that has a strong, advanced (technological) and moral philosophy. A civilization that is formed not only physically but also spiritually. 
This is the direction of Indonesian Islamic law in the new normal era, namely combining or integrating science, religion, and culture. People must continue to pray as a religious symbol, still uphold togetherness as a symbol of gemeinschaft, but people must also make efforts by wearing masks, wearing hand sanitizers, and physical distancing as symbols of science. Islamic law places great importance on individuals and togetherness built by individuals in a culture (gemeinschaft). Prophet Muhammad said: قال وسلم عليه الله صلى الله رسول أن عنه الله رضي الخدري سنان بن سعد سعيد أبي عن : (From Abu Sa'id, Sa'ad ibn Sinan al-Khudri RA, verily the Prophet SAW said: no may do actions that can endanger yourself and harm others) [12].

As for the contextuality of this hadith in the new normal era, it is recommended that we continue to work, but we must first think about whether the work can harm ourselves and others or not. If it can be dangerous, then a way must be found so that it is not dangerous. For example, we work with a cough and sneeze frequently. This can endanger ourselves or others, so preventive steps according to the hadith, the person concerned does not have to go to work or if he has to work, he has to wear a mask and be diligent with hand sanitizers.

However, currently, some people belong to the OTG group (people without symptoms), namely people without complaints, but they have been in contact with clusters indicated as covid19 so that they have the potential to transmit the coronavirus. So, those concerned in order not to harm others must pay attention to health protocols, at least wearing a mask, wearing a hand الله رسول قال :قال عنه الله رضي هريرة أبي عن : (From Abi Hurairah RA he said: that Rasulullah SAW said: "whoever harms others, Allah will pay back harm to him and whoever troubles or troubles others Allah will make it difficult for him) [13].

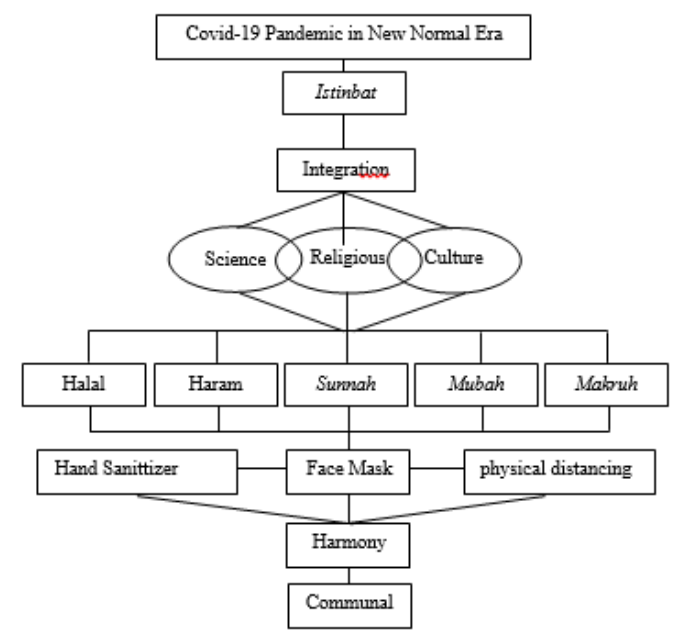

Figure 2. The Direction of Islamic Law in Indonesia in New Normal Era

Many people think that mosques and other places of worship are places for people to pray and draw closer to Allah, so there is no need to apply health protocols. In the context of the new normal, there must be aware of all levels of society, whether they enter the mosque or the market or to a large crowd anywhere. Referring to the above hadith, the health protocol must be prioritized so that any possible entry of a dangerous coronavirus is rejected as much as possible, following the rules of al-dharār yudfa'u bi qadril imkān (as much as possible damage must be rejected). 
In the end, it enters the level of al-dharār yuzālu (damage must be removed). If all people can be disciplined in adhering to the above hadith along with the rules taken from it, slowly but surely the chain of the spread of the coronavirus can be broken. To carry out the above hadith, hand washing

soap should be provided in a crowded place and running water. If possible, masks are also provided so that all people who enter mosques, markets, and other gathering places wear masks.

\subsection{The second main question is how the methodology of the direction of Indonesian Islamic law in the new normal era}

As explained in the first question above, the direction of Indonesian Islamic law in the new normal era is the implementation of the integration of science, religion, and culture. To make it happen, the methodology that must be used is multidimensional in the form of approaches to theology, jurisprudence, epidemiology, health, environment, humanities, hermeneutics, economics, sociology, and others by looking for common points.

The style and methodology of science, dealing with the physical, empirical, and rational world, mean that it must be real (acquired knowledge). Because science is real, according to Mehdi Golshani, finding the answer must be in the real world and through experimentation, observation, and theoretical reasoning. These observations will produce a rational abstraction which is then called a theory. For a theory to be accepted, it must be tested empirically using existing facts. If the truth of a theory is proven empirically, then it will be called scientific truth. However, if the theory is not tested by empirical facts, it will only become a hypothesis. And this hypothesis then becomes an open way for science to make a marriage between deduction and induction [14].

Because science is not fully correct for certain entities, because the nature of science is to develop, experience renewal, and revise the obsolete. But it must be admitted, as objectively as in science, but still, the role of the subject is needed, the subject ratio is still there. This is what Barbour said that empirical data can be interpreted depending on the researcher. This means that each individual can interpret the empirical data in different ways according to their expertise, experience, and background knowledge. Therefore, Barbour offers a theory of scientific justification with intersubjective validity [15].

Furthermore, culture (culture). Whatever is born from human activities will become a cultural object. In essence, culture is part of the humanities. Where the humanities itself has a paradigm that is contrary to science. If science emphasizes objectivity, the humanities emphasize subjectivity. Two things are the opposite. Culture (culture) is flexible or dynamic, can change from time to time and from place to place. In the view of Nurcholis Madjid, for example, that culture that is religiously based will still face changes [11]. These changes occur especially in paradigms, as religion and science also experience this. This certainly reminds us of the cultural stages classified by Van Peursen, namely:1) mystical, where humans behave based on the influence of supernatural powers,2) ontologically, humans begin to realize and distance themselves from these occult influences which then result in an assessment of the objects around them., and the last stage is 3) functional, where humans do not just assess objects, but also find a function of knowledge for themselves [14].

Therefore, there is a separate methodology in studying the humanities sciences, namely using the hermeneutic approach. By using hermeneutics, a researcher can find the complete message of an event, as well as text. Hermeneutics seeks to discover existing discourses at that time because it cannot be denied that the shift in discourse causes episteme. So, from there, a researcher can explain or communicate a complete message that becomes reliving the meaning desired by the message maker or from the incident [16]. 
Then religion as a source of knowledge in religion is the revelation (perennial knowledge) whose truth is non-negotiable. However, finding truth in revelation certainly still requires a methodology to be able to produce what message wants to be conveyed and is meant in the revelation. Justification regarding this methodology can be extracted from various approaches that are commonly used, for example in Islam, which recognizes the Bayani, Burhani, and Irfani approaches. The Bayani approach, which also refers to the textuality of a text, is not the only method of thinking recommended by the Qur'an, because there is also a rational approach called the Burhani method, plus the Irfani method which prioritizes inner experience [17].

Likewise, in the principles of fiqh as a branch of religious studies. The figh scholars have agreed (have agreed) that the methodology of determining law can use qiyas. Qiyas (which later became known as a wide analogy) in this case is a comparison that equates a new problem law with a problem law similar to what has happened earlier [18]. Which in this case certainly requires a high role of the reason (rationality) in finding polarization towards this. This means that even though the area of religion is known for its revelatory authority, the role of the human ratio is still used in capturing an essence.

Revelation offers an absolute truth because it is placed as a guide for life. However, the truth itself can be achieved through an interpretive process following the intellectual dynamics of a mufassir [19]. Thus, the meaning of faith (belief) should not be interpreted as final, but as a first step for the departure of doubts. Doubt not what he believes, but doubt whether his faith is true faith.

In other words, even though religion is subjective, it will be absurd if there is a claim from a person or group that feels truer than other people/groups. So, to avoid acute subjectivity, objectivity in religion through empirical research is needed. If this is the case, then between science, culture, and religion the three of them do not rule out the possibility of entering into a new paradigm that has been considered taboo in each domain. The paradigm shift experienced by science, culture, and religion is nothing but a way to bring the three of them together at a common point, that the three of them can run harmoniously and integrate. As stated by Golshani, the paradigm is a common area where all views from various backgrounds in this world can enter and compete to color and dominate each other, including in the paradigm of positivism, empiricism, and religion [9]. As mentioned earlier, that is where the meeting point between science, culture, and religion.

If we refer to Barbour on the map of relations, there are at least four typologies that exist, namely conflict, independence, dialogue, and integration [20]. First, conflict, the view that religion and science are two opposites, so one must choose between the two. Second, independence, namely efforts to avoid conflict by giving areas to each of these domains which are then used as strategic steps to respond to a conflict. Third, dialogue, this typology is a constructive effort between science and religion by raising considerations or exploring parallels/harmony. Fourth, integration is a more extensive and systematic effort to find harmonious relations that religion and science contribute to each other [20]. Of course, in this case, a suitable typology to offer in paradigm development is the type of dialogue or integration. Because both of them do not close the possibility of a harmonious relationship. Although this cannot be ascertained as the final paradigm in the development of science. Because until now, the discourse on the relationship between science, culture, and religion continues to look for more appropriate forms of interaction. According to Barbour, for the occurrence of integration, of course, what is most needed is no longer objective or subjective, but intersubjective validity. Intersubjective is a scientific mental position that can dialogue between the objective world and the subjective as well as in the scientist is facing the complexities between science, religion, and culture. Although the intersubjective test proposed by Barbour is taken from the approach of religious phenomenology, this cannot be separated from the context of discussing how science and humanities work. Because both the 
object and the subject each play a role in scientific activities. Where the data found (although it must be objective) cannot be said to be completely independent of the interpretation of the researcher/observer (requires subjectivity). Because creating a concept does not just exist from nature, but because of the creativity of the researcher [21].

From this dialogue-integration typology that uses intersubjective testing, the approach makes between science, culture, and religion one-unit, albeit different in the realm. If viewed from an Islamic point of view, for example, the concept of truth is only owned by God. While the verses of God we know into two parts, namely the verse al-kauniyah (which is the universe and its contents, including human culture), and the verse al-qauliyah (written in the Qur'an). The two verses of God in the form of kauniyah and qauliyah are none other than the blue-print of God or the so-called qadarullah or the power of God. Thus, the natural phenomenon (object of scientific study) does not stand alone without its relevance to the Hand of God. Therefore, when a person studies or meditates on this natural phenomenon he can know God and strengthen his faith. This is what Barbour argues that religion significantly influences attitudes toward human action motivation.

Furthermore, in the Islamic perspective, science is sacred with the following characteristics: 1) science considers the physical world as a creature of God, while the task of the intelligent person is to find out how it works. 2) science is always looking for the union that underlies the order of creation through a holistic approach. 3) science accommodates revelation and intuition to complement the understanding of reality through experimentation and theoretical reasoning. 4) science views the universe as having a meaning that extends beyond man and is connected to the purpose of existence. 5) science integrates knowledge with value.[19]

Next about culture. The object of cultural knowledge born of human work, taste, and invention cannot be said to be a stand-alone entity. Because man and his creativity that give birth to culture is nothing but a creative sub-media of God's revelations, as God created this universe.

In this case, Nurcholish Madjid explains religious and cultural relations. According to him, religion and culture are two areas that can be distinguished but cannot be separated. The proof is that most cultures are based on religion; it has never happened otherwise. Therefore, religion is primary and culture is secondary. Culture can be an expression of religious life; therefore, it is a sub-ordinate of religion, and never the other way around [11].

Similarly, what Abdurrahman Wahid meant, although between religion and culture have their independence, but the two have overlapping areas. The overlap between religion and culture will occur continuously as a process that will enrich life and make it not arid [22]. That is where the idea of Islamic Indigenization ala Abdurrahman Wahid can be accepted by the Indonesian people with its distinctive culture. When religious with all the doctrinal tools they have dialectic with the various cultures that exist in society, then that is where there is a need to mutually change the traditions they have. This means that there is a process of negotiation that sometimes results in a change in the form of each tradition, but remains on the independence of each.

Thus, of the three entities; that is, science, culture, and religion should not be interpreted as something separate, although the three are different, in reality, they can unite. By using a dialogueintegrative paradigm or approach or another term with a negotiation approach, a stable paradigm is achieved that can unite the three. 


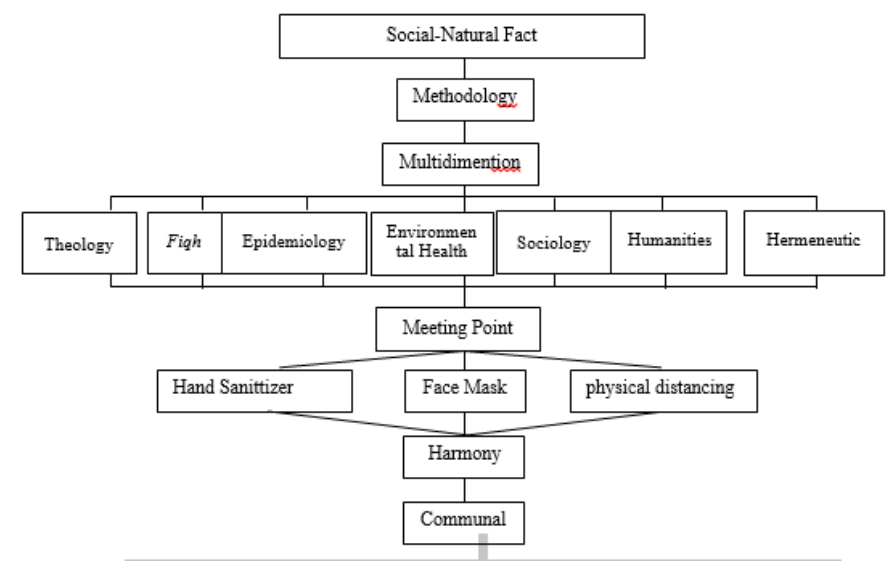

Figure 3. Methodology of The Directions of Islamic Law in Indonesia in New Normal Era

\section{Result and Discussion}

So, the covid-19 pandemic in the New normal era in Indonesia is not a punishment that makes people pessimistic, but must be understood as a disaster, which can make people optimistic to always find a way out. New normal is a period of working side by side (not getting along) with a pandemic. This means that we must continue to be active in worship and muamalah but at the same time remain consistent in avoiding the Covid-19 pandemic. For this reason, an understanding and implementation of the integration of science, religion and culture is needed by finding common ground. This is possible because science, religion and culture each accept rationality and dialectics even though they have different levels. The ability to understand and implement the integration of science, religion and culture is the direction of Indonesian Islamic law in the new normal era.

To be able to create an integration of science, religion and culture, a multidimensional methodology is needed through approaches to theology, jurisprudence, epidemiology, health, environment, hermeneutics, economics, sociology and culture by finding common ground.

\section{Conclusion}

The problem in this paper is how the direction of Indonesian Islamic law in the new normal era and how the methodology of Islamic law in determining the direction of Indonesian Islamic law in the new normal era.

First, it turns out that the direction of Indonesian Islamic law in the new normal era is the integration of science, religion and culture. In this way, Islamic law (figh) is increasingly showing its flexibility. Likewise, legal products that arise from the integration of science, religion and culture can facilitate, encourage harmony, moderation, work creativity, away from being extreme, and getting closer to the real goal of Islamic law, namely the benefit of society.

Second, it turns out that harmonizing the integration of science, religion and culture requires a multidimensional approach methodology in the form of theological, jurisprudence, epidemiology, health, environment, economics, sociology, and hermeneutics by looking for common points in determining the direction of Indonesian Islamic law in the new normal era. 
As a result of the research, this paper suggests that all human activities in the new normal era should be implemented based on the integration of science, religion and culture using a multidimensional approach methodology.

\section{References}

[1] F. Selamat, "Memprediksi new normal yang sesungguhnya," Kompas.com, 2020.

[2] S. Qalyubi, "Prinsip New Normal Dijelaskan Rasullah 14 Abad Silam," Republika.co.id, 2020.

[3] E. Wishnubrata, "Menyongsong New Normal, Apa yang Bisa Kita Lakukan?," Kompas.com, 2020.

[4] R. E. dan B. N. I. Lumbanrau, "No Title," BBC News Indonesia, 2020. .

[5] A. A. an-Nadawi, Al Qawaid al-Fiqhiyyat, Mafhumuba, Nasyiatuha, Tathawwurubah, Dirasat Muallifatiha, Adillatuha, Muhimmatuha, Tatbiqatuha. Damaskus: Dar ar Qalam, 1994.

[6] I. Q. Al-Jawziyah, l'Iam al-Muawwaqqi'in Rabb 'an al-Alamin. Beirut: Al-Fikr, t.th.

[7] A. Abdullah, "No Title," 2020.

[8] TIM MUI, "Fatwa-fatwa MUI Pusat," mui, 2020. https://tirto.id/isi-lengkap-fatwa-mui-tentang-sholatjumat-saat-pandemi-covid-19-fFlw, https://mui.or.id/berita/27674/fatwa-penyelenggaraan-ibadahdalam-situasi-terjadi-wabah-covid-19/, https://mui.or.id/produk/fatwa/27748/fatwa-no-17-tahun-2020pedoman.

[9] Hidayatullah, "Relasi Sains, Budaya dan Agama Sebuah Upaya Pendekatan Paradigma yang Menyatukan," J. Al-Maiyyah, vol. 11, no. 1, 2018.

[10] D. Muhaimin, Kawasan dan Wawasan Studi Islam. Jakarta: Kencana, 2007.

[11] A. dan Abd Hakim and Jaih Mubarok, Metodologi Studi Islam. Bandung: Remaja Rosdakarya, 29, 2000.

[12] HR. Ibnu Majah No 2340 dan 2341. .

[13] HR al-Tarmidzi dan Ibnu Majah. .

[14] J. S. Suriasumantri, Filsafat Ilmu Sejarah Pengantar Populer. Jakarta: Sinar Harapan, 2005.

[15] I. G. Barbour, Issue in Science and Religion. New York: Harper Toorchbooks, 1966.

[16] F. B. Hardiman, Melampaui Positivisme dan Modernitas. Yogyakarta: Kanisius, 2012.

[17] M. D. Rahardjo, Metodologi Studi Al Quran. Jakarta: Gramedia, 2009.

[18] A. A. B. Philips, Asal Usul dan Perkembangan Fiqh terjemahan Fauzi Arifin. Bandung: Nusamedia, 2005.

[19] Zubaedi, Islam dan Benturan Peradaban. Yogyakarta: Ar-Ruzz Media, 2007.

[20] I. G. Barbour, When Science Meets Religion. New York: Harper SanFransisco, 2000.

[21] F. Capra, The Tao of Physics: An Exploration of The Parallels Between Modern Physics and Eastern Mysticism. New York: Bantam Books, 1977.

[22] A. Wahid, Pergulatan Negara, Agama dan Kebudayaan. Jakarta: Desantara, 2001. 